Research, part of a Special Feature on Urban Sprawl

\title{
Industrial Restructuring and Urban Change in the Pittsburgh Region: Developmental, Ecological, and Socioeconomic Trade- offs
}

\author{
$\underline{\text { William Haller }}^{1}$
}

\begin{abstract}
This article traces the steel industry's restructuring during the 1980s and its consequences for older industrial regions tied historically to steel production. These regions contained large workingclass communities that declined because of deindustrialization and restructuring. This article first examines the transition of the steel industry from its roots in extractive and primary manufacturing to a scrap-recycling industry that minimizes labor and raw material inputs. This transition parallels the structural changes in other industries addressed by political economic perspectives, such as the new international division of labor and globalization of production. The article then focuses on the socioeconomic and structural changes, using the Pittsburgh region as an example, including the employment and land-use consequences of deindustrialization and the relationship between losses in manufacturing employment and increases in persistent joblessness and poverty associated with growth of the urban underclass.
\end{abstract}

Key Words: deindustrialization; economic restructuring; underclass; uneven development

\section{INTRODUCTION}

The shift from basic manufacturing to services and skill-intensive manufacturing among the advanced industrialized countries in recent decades was frequently accompanied by shifts in the geography of production. This divested older industrial regions of their primary employment and income sources in favor of alternative production sites and processes (Fröbel et al. 1980, Dicken 1992, Haller and Singh 1996, Haller 1999, Price 2001). Such places, once hosting vibrant working-class communities, sank into severe economic depression with persistently high poverty rates. Changing technological and geographical organization reduced the need for routine production workers, and also made many white-collar positions redundant. Residents of older industrial regions still live with the consequences of deindustrialization because they were unprepared to adapt to the labor-market shifts in their locales. Aside from the implications for employment, technological change and industrial restructuring have facilitated the spatial reorganization of production and urban growth, leaving inner cities with growing unemployment and shrinking tax bases.

The restructuring of metropolitan labor markets affects employment opportunity, and lack of opportunity is a primary factor contributing to the growth of an urban underclass (Wilson 1980, 1990, 1996, Anderson 1990, Singh 1991, FernándezKelly 1995). The urban underclass has been defined as the resident population of inner-city areas where the highest rates of school dropout, poverty, welfare dependency, and family disorganization intersect. These areas are highly isolated spatially, socially, and economically from mainstream society (Ricketts and Sawhill 1988, Singh 1991).

In the U.S., sprawl complicates the problems of inner-city ghettos in at least two ways. First, the hazardous waste regulations issued by the Environmental Protection Agency (EPA) produced unintended consequences. In particular, liability risk created disincentives to purchase and redevelop 
abandoned industrial sites. Jobs lost through deindustrialization, therefore, are not typically replaced by reinvestment and redevelopment in the same locales. Real-estate investment is deflected from the previously used production sites in favor of new sites along suburban fringes. As indicated by Geltman (2000:356), although Superfund has been effective in fostering pollution prevention and waste minimization, the law has inadvertently produced a chilling effect that has stymied prospective purchasers and lenders from investing in the renewal of abandoned contaminated waste sites: sites that once provided the lifeline of economic viability and jobs to thriving communities have been abandoned for fear of the contamination that might be present. This migration from "brownfields" to "greenfields" is particularly problematic in certain urban and industrial areas, where the loss of investment capital and jobs further exacerbates existing economic and social conditions.

When work disappears people are left behind, but frequently, so too are toxic releases and other industrial wastes. This stigmatizes abandoned sites, and discourages future reinvestment in them. New employment growth is directed elsewhere, often toward the suburban rings, contributing to sprawl.

Second, sprawl increases the isolation of inner-city residents by increasing the distances needed to leave the inner city. When new, entry-level job growth is concentrated in the suburban rings, a spatial mismatch is created between areas with high unemployment and those with high demand for entry-level labor. The wages these positions offer often do not cover the commuting and time costs to sustain work on a regular fulltime schedule (Kasarda 1988). Additionally, many outlets and escapes to the daily routines of urban and suburban life taken for granted as amenities by members of mainstream society are unreachable and sometimes unknown to people in the urban underclass. The more isolated and bounded-in the poor residents of urban ghettos become, the more their sense of connection to the wider biosphere on which we all depend is undermined. Far from being a quaint or trivial consideration, the connection to nature is a central component of every human society's culture. With the rapid expansion of suburban sprawl filling interurban spaces and creating polycentric megalopolises such as BosNyWash (the northeast corridor extending from Boston in the north to the District of Columbia), some local governments, e. g., the State of New Jersey, have recognized the need to maintain rural open spaces and wildlife management areas.

Restructuring in the steel industry in many ways paralleled that of other industries, such as textiles and electronics, relying on outsourcing (as emphasized in the new international division of labor and globalization of production literature). But, in the steel industry, it was only partially due to competition from imports.

\section{Global Trends in Steel Production and Trade}

Both the production and trade of finished and semifinished steel and iron ore have been increasingly internationalized since the early 1970s. This increase in the number of steel producers worldwide and in international trade occurred in the midst of an increasingly competitive and volatile world market. Using data from the Organisation for Economic Co-operation and Development (OECD) (1995), Fig. 1 shows the trends in world crude steel production plotted annually from 1970 to 1994 . The shares of this production accounted for by the U.S., nine major countries of the former European Community (EC-9: Belgium, Denmark, France, former Federal Republic of Germany, Ireland, Italy, Luxembourg, the Netherlands, and the United Kingdom), Japan, and most of the developing countries (non-members of the Organization for Economic Cooperation and DevelopmentOECD) show the primary international shifts in crude steel production. The share of world steel production unaccounted for by these countries, belongs to Russia and the other newly independent states, Central Europe, China, North Korea, and the remaining OECD members.

World crude steel production from 1970 to the mid-1990s increased by 128 million metric tons, with a peak of 703.5 million metric tons in 1974, another in 1979 at nearly 747 million metric tons, and a third to just over 645 million metric tons in 1982. Finally, a new peak of nearly 786 million metric tons was reached in 1989.

In the U.S., crude steel production declined from nearly 120 million metric tons in 1970 to nearly 89 million metric tons by 1994. Production reached its height in 1973 when nearly 137 million metric tons of crude steel were produced and later hit a low of 
Fig. 1. World crude steel production, 1970-1994.

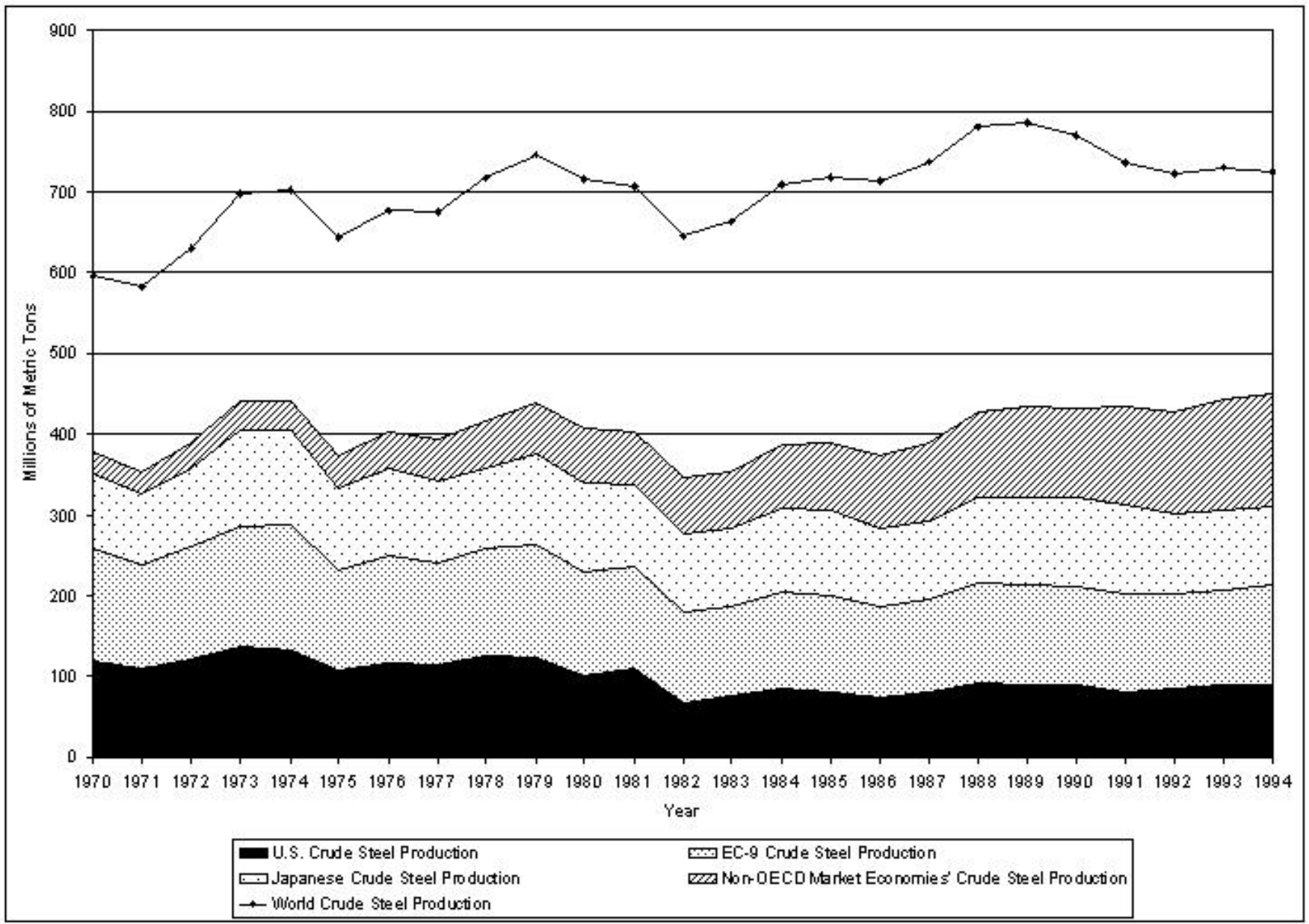

67.7 million metric tons in 1982 . In addition to this massive decline in crude steel production, the major steel companies' steel-producing divisions operated in the red for 5 consecutive years. By this time, the major steel companies were diversifying out of steel production and relegating it to unprofitable divisions.

Armco, Bethlehem, Inland, LTV, and U.S. Steel had a combined net income of -2999 million dollars in 1982 and were operating at $44.1 \%$ capacity. (Heraclito de Lima 1991:153). Recovery in the U. $\mathrm{S}$. for the steel divisions of the major steel companies was slow during the next decade (until
1993), operating at a profit only during 1987, 1989, and 1990 (American Iron and Steel Institute (AISI) 1992, 1997).

The aggregate crude steel production of the EC-9 countries roughly paralleled that of the U.S., with the peak in 1974 and the low point in 1983. Japanese crude steel production, by contrast, was relatively stable. The sharpest drop in Japanese crude steel production was from 1980 to 1981, from nearly 111.5 to just over 101.5 million metric tons. Meanwhile, crude steel production increased substantially among developing countries. In 1970, their crude output was 27 million metric tons (just 
about $22.5 \%$ of the 120 million metric tons produced by the United States during the same year). By 1994 their crude steel output had climbed to 140 million metric tons, more than one and a half times the 89 million metric ton output of the United States for the same year (and exceeding Japanese production by some 42 million metric tons, and production in the EC-9 countries by 16 million metric tons). The developing countries leading in steel production are Brazil and South Korea, followed by South Africa, India, Taiwan, Mexico, and Venezuela (Heraclito de Lima 1991). These countries are a subset of the non-OECD countries with market economies shown in Fig. 1.

Figure 2, also based on data from OECD (1995), shows the corresponding trends in world steel exports from 1970 to 1994. Compared with Japan, or the EC-9 countries combined, the U.S. does not export much of its steel. Particularly striking, however, is the developing countries' increases in steel exports-from 3 million metric tons in 1970 to about 23.5 million metric tons in 1985. By 1992, the developing countries were exporting more than 35 million metric tons of steel annually - more than a tenfold increase from 1970. However, due to the remarkable appetite for steel in their construction industries, developing countries' imports typically exceed their exports. In 1980, developing countries' combined imports reached 43 million metric tons and, by 1994, this figure surpassed 66 million metric tons.

The exports of the EC-9 countries never exceeded this amount, reaching a maximum of 34 million metric tons in 1985 and standing at some 25 million metric tons in 1994. Furthermore, most of these exports remained within Europe. Japanese steel exports reached a high of 36 million metric tons in 1976 , dropping to a plateau of approximately 30 million metric tons between 1978 and 1986. Since then, exports have declined, dropping even lower to about 20 million metric tons, with a low point of about 16.5 million metric tons in 1990. This internationalization of production and trade occurred during a period of declining demand in the advanced industrialized countries.

Using data from the AISI, Fig. 3 shows the overall decline in wage employees in the U.S. steel industry from 1970 to 1997 alongside the increasing levels of imports for the same period. Close examination of these trends does not support a tight causal relation between increases in imports and declines in wage employment. A direct link between steel imports and losses in wage employment is not supported, unless the spikes in steel imports from 1975 to 1978 and from 1980 to 1981 had a delayed or threshold effect on management decisions to cut workers. The massive drop in wage employment did not occur until 1979 to 1983.

The extremely sharp spike in the levels of steel imports from 1983 to 1984 was followed by an additional slide in the levels of wage employment in the U.S. steel industry from 1984 to 1987. From 1988 onward, wage employment in steel has been declining gradually, to an estimated 83500 workers in 1997. The increased levels of steel imports in the U.S. market from the period of 1975 to 1984 doubtlessly contributed to the employment decreases in the U.S. steel industry by increasing the competitive pressures on the major U.S. producers. However, foreign competition was not exclusively to blame. The overall demand for steel in the U.S. declined and technological advancements that minimize labor inputs permitted scrap-based steel production to capture greater shares of a shrinking market.

Advancements in production technology permitted scrap-based production to compete with ore-based production-radically altering the economics of production site choices. The globalization of the steel industry not only meant increased international trade and overseas competition but increased domestic competition due to the irrelevance of the geological characteristics of older steel-producing regions for newer, scrap-based production. These labor-saving technologies truncated the production chain, sidestepping both organized labor and transportation costs.

The remainder of this article addresses adaptation of the steel industry to competitive pressures, and the consequences for the local economic and social structure in the Pittsburgh region. There is some truth to industry claims that its new forms of production are environmentally friendlier. The shift in steel production to a recycling-intensive industry has been beneficial to the environment and sustainable development by reducing smokestack emissions and surface water runoff from abandoned mines. These environmental improvements in the Pittsburgh region are shown in Gdovic and Haller (1994) using data from the EPA's AIRS and STORET archives of air and water quality data. 
Fig. 2. World steel exports, 1970-1994.

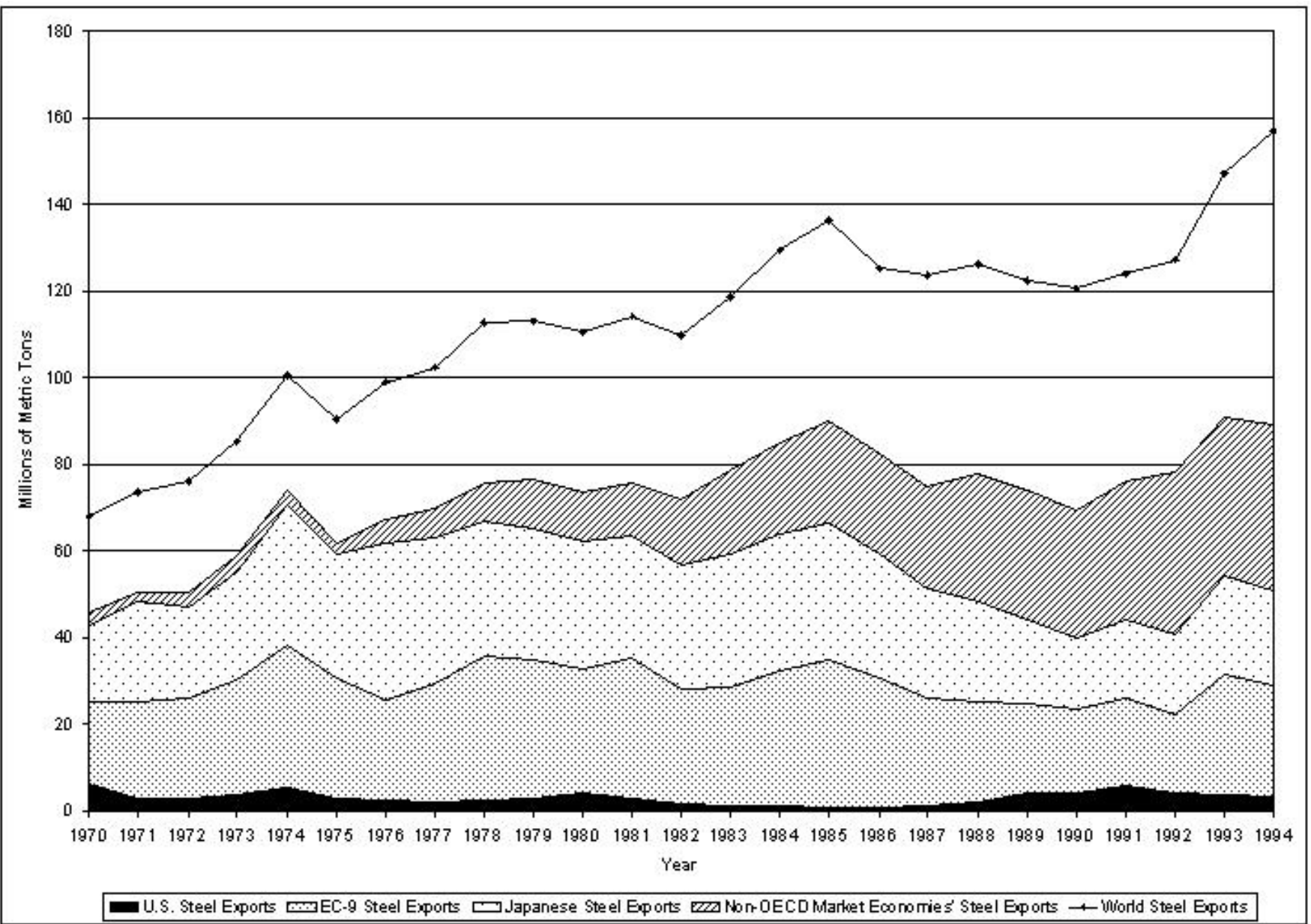

Downsides include the emergence of urban brownfield sites, the geographical dispersion of production to numerous greenfield sites, and the consequent deterioration of quality of life for urban residents, particularly the poor.

\section{Restructuring Steel Production: Spatial Deconcentration and the Shift from Steelmaking to Reprocessing}

From the 1940s to the late 1970s, large integrated plants in the U.S. provided living wages for hundreds of thousands of steel workers and their families. But, in the early 1980s, the major U.S. producers cut their operations in these plants because they had lost their economic viability. The trends in steel production and trade leading to this loss were the technological, economic, and political forces governing the prices and demand for steel products: 1) increased energy costs, 2) lighter, energy-efficient substitutes, such as advanced plastics and aluminum alloys, and 3) growing stockpiles of recyclable scrap steel. This third factor was decisive, because new electric furnace technologies were scrap based. These technologies permitted a new type of steel plant, the minimill, to be deployed at locations with large scrap supplies, 
Fig. 3. Wage employment and imports, U.S. steel industry, 1970-1997.

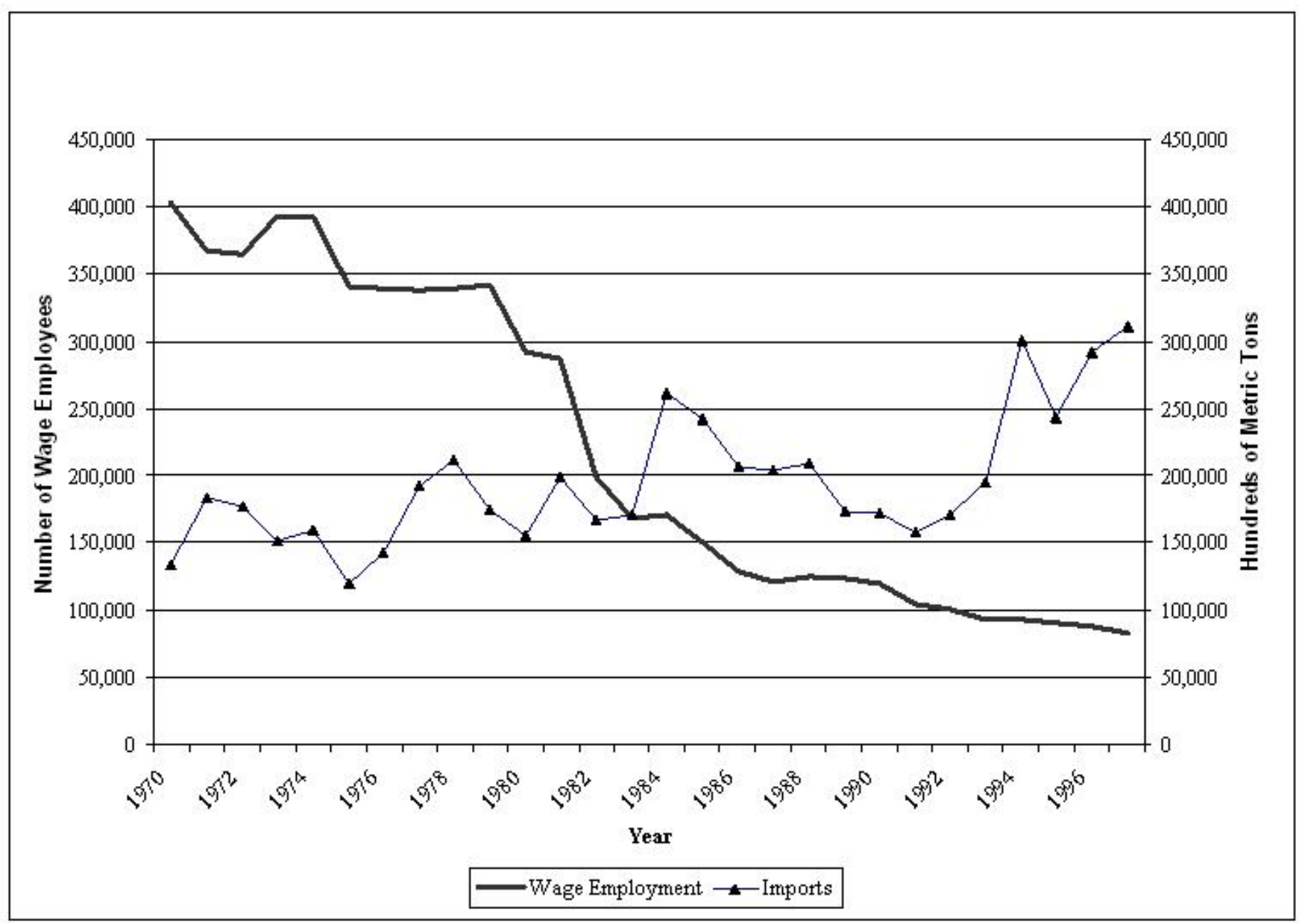

bypassing the constraints of the large integrated plants that required sites near sources of coal, iron ore, and limestone. Taking production sites to the material inputs, rather than the material inputs to the production sites cut transportation costs which "loom large for a relatively low-value product such as steel" (Barnett and Crandall 1986:23). The production concept on which the minimills are based-recycling local scrap with minimal labor inputs for proximate markets-contrasts with traditional steel production, which evolved into the large integrated plants equipped for centralized mass production for the national market.

\section{Shifts in Steel Production Technology}

In traditional steelmaking, there are three production stages: 1) the reduction of iron ore into pig iron, 2) the transformation of pig iron into steel, and 3 ) the finishing to give the steel its required shapes and properties (Heraclito de Lima 1991). Large, integrated steel plants were designed for all three tasks, relying on coking coal, iron ore, and limestone as basic inputs (Barnett and Crandall 1986). This overall process is described as ore-based production, as opposed to the scrap-based, or recycling, production of the minimills (Beeson and Giarratani 1998). The furnace technologies used during the second half of the $20^{\text {th }}$ century included open hearth, basic oxygen, and electric. Open 
hearths are now obsolete. The remaining large, integrated plants rely on basic oxygen furnaces, sometimes augmenting them with electric furnaces (Barnett and Crandall 1986). By contrast, minimills rely on electric furnaces and scrap steel (or, rarely, directly reduced iron) for inputs. The increased production of electric furnaces over basic oxygen furnaces represented a shift from large integrated plants to minimills. Each major furnace technology increased efficiency - either within the integrated plants or by the minimills - and also cut labor. Some integrated plants persist because minimills are not yet capable of producing the same range of products. As Heraclito de Lima (1991:8) states, "The technology to produce flat-rolled products was costeffective only at the large scales attained by the integrated producers." Additionally, impurities in scrap steel mean that certain grades of high-quality steel are still unattainable by minimills. However, scrap-based technologies are continually being improved, cutting into the remaining demand for steel from basic oxygen furnaces.

Compare the three stages of ore-based steel production to the minimills' production. The first stage, reducing ore into pig iron, is bypassed by minimills because their inputs rely on preexisting sources of scrap steel, and do not require primary processing of raw materials. In the second stage, after pig iron is produced, it is promptly converted to molten steel before it solidifies. Typically, this required an open hearth or basic oxygen furnace. Minimills also bypass this stage.

The third stage is finishing. Before continuous casters were invented, finishing was not a one-shot process. Molten steel was poured into molds and allowed to cool into ingots. Afterwards, "the ingots are heated to a temperature of 1000 to 1200 degrees Celsius in "soaking pits" and then rolled" (Heraclito de Lima 1991:7). By contrast, continuous casting technology pours and forms the molten steel directly into the desired semifinished shapes, bypassing the ingot stage entirely. The continuous caster also yields products with greater metallurgic consistency (Barnett and Crandall 1986:5). In the U.S., continuous casters are used almost exclusively in minimills because retrofitting them to the basic oxygen furnaces in integrated plants is costly. The quality enhancement gained by continuous casting helps minimills offset the quality reductions caused by impurities found in scrap steel.

In contrast to the extensive process required by traditional ore-and-coke steelmaking, minimills typically "charge" scrap back into molten steel in an electric furnace and roll it out into finished or semifinished shapes in a continuous caster. The effects of decreased demand for steel and increased competition from imports and minimills during the 1970 s and 1980s were devastating to the large, integrated plants. As indicated by Beeson and Giarratani (1998:425), "these factors led to a 30percent decline in ore-based steel-making capacity at the integrated mills by 1991, and the closure of 22 of the 45 ore-based mills that were in operation in 1974. At the same time that the integrated sector was contracting, the minimill sector....was expanding, adding 18.3 million tons of scrap-based capacity." As an alternative production concept allowing radical cost cutting, the minimill fits the general observations of the new international division of labor and globalization of production perspective, even if its cost reductions accrue through technology and innovation rather than the exploitation of low-wage offshore labor.

Figure 4 shows overall crude steel output by type of furnace, using data from the AISI. The disappearance of open-hearth steel production can be seen in the bottom band, and the increasing proportions of crude steel produced by electric furnace technology, accounting for most minimill production in the U.S., is in the top band. The amounts of crude steel from basic oxygen furnaces are shown in the middle.

\section{Plant Closures and Manufacturing Employment Losses in the Pittsburgh Metropolitan Area}

Traditionally, steel employment was concentrated in a limited number of production regions where large-scale integrated plants developed. Economic restructuring, prevalent in manufacturing since the mid-1970s, intensified during the 1980s. Just as the sectors affected by restructuring were not isolated to steel, or even to manufacturing, the regions where employment was disproportionately affected by restructuring were also widespread. Singh and Borzutsky (1988) compare Pittsburgh's manufacturing losses with other U.S. regions with large urban cores (Chicago, St. Louis, Birmingham, Philadelphia, Cleveland, and Detroit), and with older steelproducing regions overseas (Nord-Pas de Calais in France, Ruhrgebeit in Germany, and Glasgow in Scotland). Koritz (1991) shows that the effects of 
Fig. 4. Steel output by type of production technology, U.S. 1970-1998.

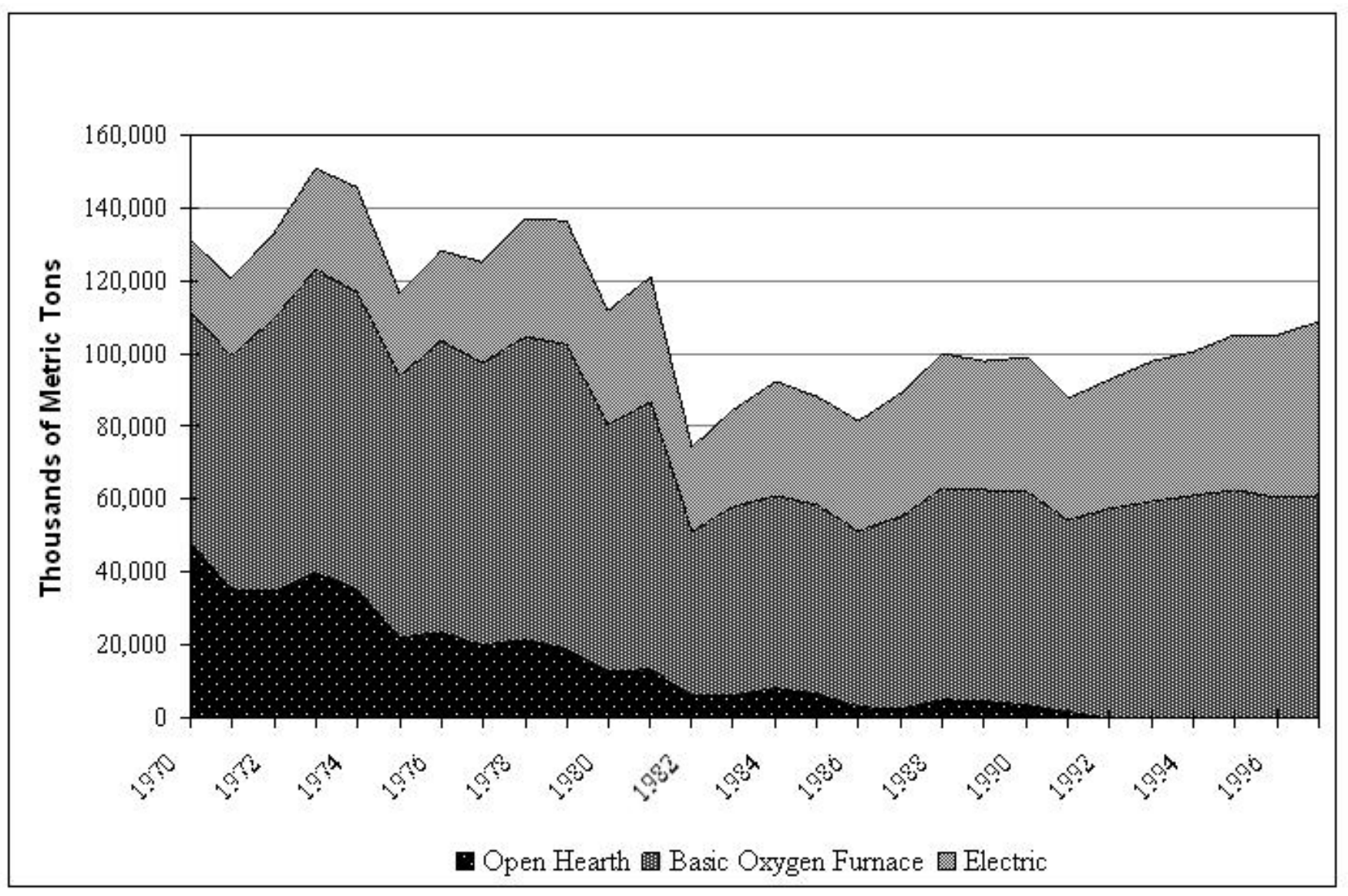

deindustrialization on Pittsburgh's economy, unlike some regions such as Buffalo, New York, were buffered because of its high concentration of major banks and corporate headquarters. Thus, whereas Pittsburgh restructured, Buffalo "destructured."

Because steel is used in many manufactured goods, demand for steel declined as lighter, cheaper substitutes were developed. Competitive pressures in the industry increased as a result of technological changes and imports, while the market for steel in the advanced industrialized countries was shrinking. In the U.S., the regional concentration of steel employment meant that employment declines were focused disproportionately on specific communities. Because job searches of less-skilled and unskilled workers tend to remain within local labor markets, the disproportionate impacts of deindustrialization in specific regions compounded the redundancy of laid-off workers in these places. The following analyses of the socioeconomic impacts of the restructuring of the steel industry centers on the Pittsburgh region, which grew in tandem with big steel and its overall role in the early industrial development of the U.S.

To indicate the magnitude of manufacturing employment losses in the Pittsburgh region during this time, data in Table 1, from the U.S. Bureau of Economic Analysis's Regional Economic Information System (REIS), compare manufacturing and nonmanufacturing employment between the Pittsburgh region and the U.S. economy for the periods 19761986 and 1986-1996.

The concentration of manufacturing employment 
Table 1. Manufacturing and non-manufacturing employment in the U.S. and in the Pittsburgh Region, 1976-1996

\begin{tabular}{|c|c|c|c|c|c|c|}
\hline \multirow[b]{2}{*}{ Employment } & \multicolumn{3}{|c|}{ Year } & \multicolumn{3}{|c|}{ Percent Change } \\
\hline & 1976 & 1986 & 1996 & 1976-1986 & 1986-1996 & $1976-1996$ \\
\hline \multicolumn{7}{|c|}{ Panel A: United States } \\
\hline Manufacturing & 19372300 & 19489700 & 19231500 & 0.6 & -1.3 & -0.7 \\
\hline $\begin{array}{l}\text { Non-manufactu- } \\
\text { ring }\end{array}$ & 78252900 & 104116500 & \multicolumn{2}{|c|}{13014840033.1} & 25.0 & 66.3 \\
\hline Total $*$ & 97625200 & 123606200 & 149379900 & 26.6 & 20.9 & 53.0 \\
\hline \multicolumn{7}{|c|}{ Panel B: Pittsburgh Region } \\
\hline Manufacturing & 251771 & 137306 & 119073 & -45.5 & -13.3 & -52.7 \\
\hline $\begin{array}{l}\text { Non-manufactu- } \\
\text { ring }\end{array}$ & 792803 & 888254 & 1042792 & 12.0 & 17.4 & 31.5 \\
\hline Total* & 1044574 & 1025560 & 1161865 & -1.8 & 13.3 & 11.2 \\
\hline
\end{tabular}

Source: Regional Economic Information System (U.S. Bureau of Economic Analysis 1997)

* Totals refer to non-farm employment

represented by steel in Table 1 is, of course, greater for the Pittsburgh region than for the U.S. as a whole. Nevertheless, other manufacturing sectors in the Pittsburgh region were tied to steel and also vulnerable, yielding upstream impacts in the broader local manufacturing economy. As Hoerr (1988:570) explains, "Each 1000 jobs lost in the primary metals industry forces the loss of an additional 130 jobs at firms that supply that industry." These sharp declines in the Pittsburgh region's manufacturing base occurred mainly during the early 1980s. Table 2 shows the sequence of closures among the large, integrated steel plants in the region during this period.

\section{Deindustrialization and the Underclass}

The consequences of restructuring in older industrial regions of the U.S. have been associated with multiple interrelated phenomena that include spatial, economic, demographic, and behavioral components (Singh 1991:506). Examples include weak labor-force attachment among adults, extreme poverty, high dropout rates among teenagers, unwed parenting, and welfare dependency. These phenomena are commonly associated with community distress that perpetuates poverty and isolation. As research on the underclass accumulated, several indicators came into use to measure it. Ricketts and Sawhill (1988) proposed underclass areas be identified as census tracts with scores of one standard deviation above the national mean or higher for: 1) males 16 years or older unemployed or not in the labor force (MNLFU); 2) households headed by women with at least one child and no spouse present (WHEAD); 3) households receiving public assistance (ASSIST); and 4) youths aged 16-19 neither in school nor high school graduates (DROPOUT). These places tend to be concentrated only within the most isolated areas of inner-city ghettos. An alternative criterion is extreme poverty - census tracts where the poverty rate is $40 \%$ or higher (Wilson 1993, Massey and Denton 1993). The criterion of $40 \%$ of households below the poverty line for extreme poverty areas corresponds to ghetto areas based on observation of housing conditions in these areas and the judgments of city and local census officials (Wilson 1993:13n).

Ricketts and Sawhill's criterion for underclass areas is extremely stringent. Tracts which are one 
Table 2. Integrated steel plant closures in the Pittsburgh region since 1982

\begin{tabular}{lc}
\hline \hline Company, Plant Name, and Location & Year \\
\hline USS Carries Furnaces, Rankin & 1982 \\
USS Duquesne Works, Duquesne & 1984 \\
USS Clairton Works, Clairton* & 1984 \\
J\&L Pittsburgh South Side, Pittsburgh & 1985 \\
J\&L Hazelwood Works, Pittsburgh* & 1985 \\
USS Homestead Works, Homestead & 1986 \\
Wheeling-Pittsburgh Monesson Works, & 1986 \\
Monesson & 1987 \\
USS National Works, McKeesport & \\
USS Christy Park Works, McKeesport** & \\
LTV Aliquippa Works, Aliquippa*** & \\
USS Edgar Thompson Works, Braddock*** & \\
\hline
\end{tabular}

Sources: Hoerr 1988, Heraclito de Lima 1991, Hall 1997

Notes:

* Coke production was maintained after the indicated year.

** Sold in 1986.

*** Production capacity sharply curtailed during mid-1980s, LTV

Aliquippa's ore-based capacity was eliminated by 1991.

The J\&L plants in Pittsburgh were bought by LTV prior to closure.

USS National Works in McKeesport were previously owned by Republic Steel.

standard deviation or more above the national mean for all these indicators simultaneously are very rare. To meet this criterion based on the 1980 census, for example, a tract must have 1) $56 \%$ of males 16 and older unemployed or not in the labor force; 2) $60 \%$ of households headed by women with at least one child and no spouse present; 3) 34\% of households on public assistance; and 4) $36 \%$ of youths 16-19 neither in school nor high school graduates. Nevertheless, census tracts fitting the extreme poverty criterion for the underclass are commonplace. Ricketts and Sawhill's criterion, therefore, excludes most of the places which would be defined as underclass by others because of high rates of unwed parenting, dropping out, and welfare dependence combined.

Three of the four variables comprising Ricketts and Sawhill's criterion are behavioral variables, providing a restrictive definition of the underclass and underestimating its size according to the extreme poverty criterion. If high rates of male joblessness and poverty (structural variables) are caused by major changes in regional employment structure, then it is useful to distinguish those who are structurally underclass from those who are behaviorally underclass, particularly if the structural underclass variables are mutually reinforcing. The link from joblessness to poverty is obvious. Poverty, on the other hand, may reinforce joblessness because many employers screen out residents of poor inner-city neighborhoods (Wilson 1996). The resulting situation maintains poverty that is persistent and, for many, virtually inescapable. When regional structural change expands the proportion of an urban population in poverty, a structural underclass is producedirrespective of any behavioral variables. 


\section{METHODS}

Two methods, both using census tracts as units of analysis, examine the relationship between regional restructuring and underclass growth in the Pittsburgh Standard Metropolitan Statistical Area (SMSA). The first is a tabular presentation of the relevant descriptive statistics showing the intercensal shifts in employment structure by industry and occupation during the 1970s and 1980s, and also the shifts in the five underclass indicators discussed above for the same periods. The second is a series of eight ordinary least squares (OLS) multiple regression models testing whether the intercensal employment shifts in durable manufacturing industries and blue-collar occupations (combining occupational categories of "precision production" with "machine operators") were significantly related to increases in a structural underclass (poverty and males aged 16 or older not in the labor force or unemployed). The data sources, variables, and comparability issues are discussed in the Appendix.

The change variables in the regression models are constructed by subtracting the relevant proportions of the population in a tract from the earlier time point from those in the tract at the later time point. For example, employment change in durable manufacturing industries between 1980 and 1990 is the proportion employed in durable manufacturing in 1990 subtracted from the proportion employed in durable manufacturing in 1980. This is the same operationalization for deindustrialization used by Alderson (1997), except that it is applied to census tracts rather than nation-states. Such change variables were also constructed for employment in blue-collar occupations, males age 16 and older not in the labor force or unemployed, and persons below the poverty line.

Eight multiple regression models are used to cover the two intercensal periods, 1970-1980 and 19801990, and four models sharing a similar set of independent variables. In the first set of four models, the dependent variable is either change in the proportion of males aged 16 and older not in the labor force or unemployed, or change in the proportion of the population below the poverty line. Each of these dependent variables is regressed on change in durable manufacturing and change in blue-collar occupations, controlling for size of the African American population, and whether the tract was located in the central city or suburbs.
The next set of four regression models are the same, except with one important modification: the dependent variable that was not used in the previous version of the model is now introduced as an independent variable. Thus, in these next four models, poverty is tested as a predictor of joblessness, and joblessness as a predictor of poverty. Or, more precisely, change in the proportion of the population below the poverty line is included as a predictor of change in the proportion of males aged 16 and older not in the labor force or unemployed, and vice versa.

The statistical significance tests conducted are standard for OLS multiple regression models: $t$-tests for each of the independent variables and the intercept at the alpha $=.05$ significance level, and the $p$-value for the global $F$-test of each entire model is reported. One-tailed $t$-tests are reported for the variables in the 1980-1990 period, where the direction of the relationship with the dependent variable is predicted by theory (e.g., deindustrialization increases joblessness, therefore, change in the proportion employed in durable manufacturing is negatively related to the proportion of working-age males not in the labor force or unemployed). Because the greatest number of plant closures and layoffs in the Pittsburgh region occurred between 1980 and 1990, the one-tailed $t$-tests are restricted to this period. The regression models for the 1970 1980 period are provided for comparison to highlight the 1980-1990 period.

Finally, to highlight the effects of these structural changes in the Pittsburgh region for its poorest neighborhoods and for their impact on the working and middle classes, tabulations of the underclass indicators for the extreme poverty tracts and the constant-dollar income distributions for each census decade are shown for the region as a whole, and split by whether whites or African Americans constitute the majority residing in the tract.

\section{RESULTS}

\section{Industrial and Occupational Shifts and Changes in the Underclass Indicators in the Pittsburgh Metropolitan Area}

Shifts in the proportion of employment by industry for the Pittsburgh region are presented in Table 3 . The most pronounced trend was in durable 
Table 3. Employment by industry in 1970, 1980, and 1990, Pittsburgh Standard Metropolitan Statistical Area

\begin{tabular}{lrrrrrr}
\hline \hline & \multicolumn{3}{c}{ Percent of Total } & \multicolumn{3}{c}{ Percent Change } \\
\hline & 1970 & 1980 & 1990 & $1970-1980$ & $1980-1990$ & $1970-1990$ \\
Extractive & 1.6 & 1.8 & 1.4 & 0.2 & -0.4 & -0.2 \\
Construction & 5.3 & 5.3 & 5.9 & 0.0 & 0.6 & 0.6 \\
Durable Manufacturing & 25.9 & 20.6 & 10.2 & -5.3 & -10.4 & -15.7 \\
Nondurable Manufacturing & 5.8 & 5.0 & 4.3 & -0.8 & -0.7 & -1.5 \\
Tranportation & 4.2 & 3.9 & 5.3 & -0.3 & 1.4 & 1.1 \\
Communication & 2.9 & 2.8 & 2.8 & -0.1 & 0.0 & -0.1 \\
Wholesale & 4.0 & 4.2 & 4.6 & 0.2 & 0.4 & 0.6 \\
Retail & 16.4 & 17.1 & 20.0 & 0.7 & 2.9 & 3.6 \\
Financial Services & 4.5 & 5.4 & 7.1 & 0.9 & 1.7 & 2.6 \\
Business Services & 3.3 & 4.8 & 4.8 & 1.5 & 0.0 & 1.5 \\
Personal Services & 4.3 & 3.5 & 4.0 & -0.8 & 0.5 & -0.3 \\
Health Services & 6.2 & 8.7 & 11.6 & 2.5 & 2.9 & 5.4 \\
Education & 7.4 & 8.1 & 8.5 & 0.7 & 0.4 & 1.1 \\
Other Professional Services & 4.2 & 4.4 & 7.4 & 0.2 & 3.0 & 3.2 \\
Public Administration & 4.1 & 3.4 & 3.1 & -0.7 & -0.3 & -1.0 \\
Total Employed & 870902 & 938432 & 923049 & & & \\
\hline
\end{tabular}

Sources: U.S. Census: 1970 Pop4A, 1980 STF3A, 1990 STF3A

manufacturing industries, which includes all sectors of steel production. In 1970, more than one quarter of the region's employment was concentrated in durable manufacturing. From 1970 to 1980 , the share of the region's employment in durable manufacturing shrank by more than $5 \%$, but from 1980 to 1990 , the durable manufacturing share of employment in the region shrank by more than $10 \%$. Another important aspect of employment changes in the region between 1970 and 1980, and between 1980 and 1990, can be seen in total employment. The employment decline in durable manufacturing during the 1970s took place within the context of a growing job base. Table 3 shows that the greater employment decline in durable manufacturing industries during the 1980 s was so large that it reduced overall employment in the region.

Employment trends by occupational category for the Pittsburgh SMSA are presented in Table 4. Declines in blue-collar production jobs, as expected with declines in durable manufacturing industries, can be seen in two of the broad occupational categories, "Machine Operators, Assemblers, and Inspectors" and "Precision Production, Craft, and Repair Occupations." Other industrial sectors also employed workers whose jobs fell within these categories, so their decline does not mirror durable manufacturing. Nevertheless, the drop in bluecollar employment at the regional level was substantial: among machine operators, nearly 30 
Table 4. Employment by occupation in 1970, 1980, and 1990, Pittsburgh Standard Metropolitan Statistical Area

\begin{tabular}{lrrrrrr}
\hline \hline & \multicolumn{3}{c}{ Percent of Total } & \multicolumn{3}{c}{ Percent Change } \\
\hline & 1970 & 1980 & 1990 & $1970-1980$ & $1980-1990$ & $1970-1990$ \\
Executive & 7.3 & 9.5 & 12.2 & 2.2 & 2.7 & 4.9 \\
Professional & 12.2 & 12.8 & 15.6 & 0.6 & 2.8 & 3.4 \\
Technical & 3.6 & 3.4 & 4.4 & -0.2 & 1.0 & 0.8 \\
Sales & 7.9 & 10.2 & 12.5 & 2.3 & 2.3 & 4.6 \\
Administrative Support & 18.1 & 17.6 & 17.3 & -0.5 & -0.3 & -0.8 \\
Private Household & 1.0 & 0.4 & 0.3 & -0.6 & -0.1 & -0.7 \\
Protective Service & 1.4 & 1.6 & 1.6 & 0.2 & 0.0 & 0.2 \\
Other Service & 10.4 & 11.5 & 12.3 & 1.1 & 0.8 & 1.9 \\
Farming, Forestry and & 0.5 & 0.6 & 0.9 & 0.1 & 0.3 & 0.4 \\
Fishing & & & & & -2.3 & -5.1 \\
Precision Production & 15.5 & 13.0 & 10.4 & -2.5 & -2.6 & -8.2 \\
Machine Operators & 12.8 & 8.7 & 4.6 & -4.1 & -4.1 & -0.1 \\
Transportation & 4.0 & 5.1 & 3.9 & 1.1 & -1.2 & -1.4 \\
Handlers and Laborers & 5.4 & 5.5 & 4.0 & 0.1 & -1.5 & \\
Total Employed & 870902 & 938432 & 923049 & & & \\
\hline
\end{tabular}

Sources: U.S. Census: 1970 Pop4A, 1980 STF3A, 1990 STF3A

000 jobs were lost to the Pittsburgh SMSA from 1970 to 1980 , and an additional $39000+$ were lost from 1980 to 1990. Although the occupational category of handlers and laborers can also be considered blue-collar, this group was not included with the blue-collar category here because it represents relatively low-paid work compared with machine operators and precision production workers.

The changes in the underclass indicators from 1970 to 1980 , and from 1980 to 1990 , for the Pittsburgh SMSA as a whole are given in Table 5. In summary, deindustrialization in the Pittsburgh region during the 1980s had a profound effect on joblessness among males, and a substantial effect on the poverty rate. It should be noted, however, that these effects were not evenly distributed throughout the region, particularly because these effects were magnified in predominantly African-American communities and in working-class communities outside the city limits (Haller 1999).

\section{Impacts of Employment Shifts}

The regression models testing the relationship between the economic restructuring of the Pittsburgh region and increases in structural underclass indicators are shown below. The first set of these results is shown in Table 6. As can be seen in Panel A, from 1980 to 1990, declines in durable manufacturing employment, as expected, are 
Table 5. Average percentages for underclass indicators in 1970, 1980, and 1990, Pittsburgh Standard Metropolitan Statistical Area

\begin{tabular}{lrrrrrr}
\hline \hline & \multicolumn{2}{c}{ Percent of Total } & \multicolumn{3}{c}{ Percent Change } \\
\hline & 1970 & 1980 & 1990 & $1970-$ & $1980-$ & $1970-$ \\
& & & & 1980 & 1990 & 1990 \\
Males 16 and older not in labor force or unemployed & 27.9 & 16.4 & 39.2 & -11.5 & 22.8 & 11.3 \\
Population 16 and older below poverty* & 10.7 & 10.7 & 14.6 & 0 & 3.9 & 3.9 \\
Youths not attending school and not high school graduates** & 9.4 & 5.6 & 8.5 & -3.8 & 2.9 & -0.9 \\
Households on public assistance income*** & 5.8 & 9.6 & 9.7 & 3.8 & 0.1 & 3.9 \\
$\begin{array}{l}\text { Households headed by women with at least one child, no spouse } \\
\text { present*** }\end{array}$ & 5.4 & 5.1 & 6.0 & -0.3 & 0.9 & 0.6 \\
\hline
\end{tabular}

Sources: U.S. Census: 1970 Pop4A, 1980 STF3A, 1990 STF3A

*Poverty figures are for previous year

**1970 covers 16- to 21 -year-olds; 1980 and 1990 cover 16- to 19-year-olds

$* * * 1970$ covers families, not households

significantly related to increases in male joblessness, with a slope of -0.30 . Likewise, declines in blue-collar employment are significantly related to increases in male joblessness, but with a more gradual slope $(-0.12)$. The proportion of the African-American population was also significant with a slope of -0.21 . Central city residence addresses the spatial mismatch argument (Kasarda 1988). Because of the historical concentration of basic manufacturing outside the city, particularly in the Mon Valley, the Pittsburgh region did not conform closely to the spatial employment patterns typical of many American cities (and it is not significant in any of the models for the period from 1980 to 1990). This model explains $32 \%$ of the variation in increases in male joblessness from 1980 to 1990.

During the period 1970-1980, residence in predominantly African-American areas was negatively associated with male joblessness. Federal discrimination lawsuits over unfair employment and promotion practices in the steel industry placed employers in southwestern Pennsylvania under close federal scrutiny over their dismal track record on racial inclusion. Dickerson (1986) described this as a Pyrrhic victory for African-Americans in southwestern Pennsylvania because gains from the decades-long legal struggle, resulting in a small step toward parity with whites, were lost during the 1980s.

As seen in Panel B, the same set of independent variables does not predict poverty growth as well as growth in male joblessness. Declines in durable manufacturing employment are significantly related to poverty growth but changes in blue-collar employment are not. Additionally, the proportion of the African-American population was significantly related to poverty growth from 1980 to 1990 . In all the models in Table 6 , the $p$-value for the global $F$ test was less than -0.0001 .

In Table 7, the mutually reinforcing aspects of the structural characteristics of the underclasspoverty and joblessness - increase substantially the predictive power of these models during deindustrialization. Increases in male joblessness from 1980 to 1990 explained by the model jumps to $44 \%$ by adding poverty as a predictor, and the increases in male joblessness added to the model predicting poverty increases raise the explanatory power from $8 \%$ to $23 \%$. All the other independent variables in this model become insignificant by this sole modification, suggesting that their contributions to poverty operate via joblessness. As in Table 6, for all the models in Table 7, the $p$-values for the 
Table 6. Unstandardized coefficients for regional restructuring estimates on change in proportion of jobless males and population in poverty, Pittsburgh Standard Metropolitan Statistical Area

\begin{tabular}{|c|c|c|}
\hline Independent Variables & 1970-1980 & 1980-1990 \\
\hline \multicolumn{3}{|c|}{ Panel A: Change in males, 16 and older not in the labor force or unemployed } \\
\hline Durable manufacturing & $0.18 * *(0.047)$ & $-0.29 * * *(0.046)$ \\
\hline Blue collar occupations & $-0.09 *(0.047)$ & $-0.11 *(0.063)$ \\
\hline Black Population & $-0.04 * * *(0.009)$ & $0.21 * * *(0.015)$ \\
\hline Central city & $-0.02 * * *(0.006)$ & $0.01(0.008)$ \\
\hline Constant & $-0.10 * * *(0.005)$ & $0.16 * * *(0.007)$ \\
\hline$R$-squared & 0.08 & 0.32 \\
\hline$n$ & 612 & 611 \\
\hline$F$ & $12.42^{\dagger}(4607$ d.f.) & $72.84^{\dagger}(4606$ d.f.) \\
\hline Type of test & two-tailed & one-tailed \\
\hline \multicolumn{3}{|c|}{ Panel B: Change in population below the poverty line } \\
\hline Durable manufacturing & $-0.14 * * *(0.036)$ & $-0.11 * *(0.039)$ \\
\hline Blue collar occupations & $0.07(0.036)$ & $0.00(0.053)$ \\
\hline Black population & $-0.02 *(0.008)$ & $0.08 * * *(0.013)$ \\
\hline Central city & $0.03 * * *(0.005)$ & $-0.00(0.007)$ \\
\hline Constant & $-0.01 *(0.004)$ & $0.02 * *(0.006)$ \\
\hline$R$-squared & 0.09 & 0.08 \\
\hline$n$ & 612 & 611 \\
\hline$F$ & $15.06^{\dagger}$ (4607 d.f.) & $12.79^{\dagger}$ (4606 d.f.) \\
\hline Type of test & two-tailed & one-tailed \\
\hline
\end{tabular}

Probabilities of $t: * p<0.05 * * p<0.01 * * * p<0.001$

Probability of F: ${ }^{\dagger}<0.0000$

Sources: U.S. Census: 1970 POP4A, 1980 STF3A, 1990 STF3A

Note: Standard errors (and degrees of freedom indicated by d.f.) are given in parentheses.

global $F$-test were less than -0.0001 .

\section{Correlates of Underclass and Extreme Poverty in the Pittsburgh Region}

The 1990 census reveals no tracts in the Pittsburgh region meeting the full set of Ricketts and Sawhill's criterion (discussed above). Nevertheless, the number of extreme poverty tracts increased 
Table 7. Unstandardized coefficients for regional restructuring estimates and relationships between structural underclass indicators, Pittsburgh Standard Metropolitan Statistical Area

\begin{tabular}{|c|c|c|}
\hline Independent Variables & $1970-1980$ & $1980-1990$ \\
\hline \multicolumn{3}{|c|}{ Panel A: Change in males 16 and older not in the labor force or unemployed } \\
\hline Population below poverty line & $-0.03(0.053)$ & $0.48 * * *(0.044)$ \\
\hline Durable manufacturing & $0.18 * * *(0.048)$ & $-0.24 * * *(0.043)$ \\
\hline Blue collar occupations & $-0.08 *(0.048)$ & $-0.12 *(0.057)$ \\
\hline Black population & $-0.04 * * *(0.010)$ & $0.18 * * *(0.014)$ \\
\hline Central city & $-0.02 * * *(0.006)$ & $0.01(0.008)$ \\
\hline Constant & $-0.10 * * *(0.005)$ & $0.15 * * *(0.006)$ \\
\hline$R$-squared & 0.08 & 0.44 \\
\hline$n$ & 612 & 611 \\
\hline$F$ & $9.97^{\dagger}(5606$ d.f $)$ & $93.40^{\dagger}(5605$ d.f. $)$ \\
\hline Type of test & two-tailed & one-tailed \\
\hline \multicolumn{3}{|c|}{ Panel B: Change in population below the poverty line } \\
\hline Jobless males & $-0.02(0.031)$ & $0.34 * * *(0.031)$ \\
\hline Durable manufacturing & $0 .-14 * * *(0.037)$ & $-0.01(0.037)$ \\
\hline Blue collar occupations & $0.07 *(0.037)$ & $0.04(0.048)$ \\
\hline Black population & $-0.02 * *(0.007)$ & $0.01(0.014)$ \\
\hline Central city & $0.03 * * *(0.005)$ & $-0.00(0.007)$ \\
\hline Constant & $-0.01 *(0.005)$ & $-0.04 * *(0.007)$ \\
\hline$R$-squared & 0.09 & 0.23 \\
\hline$n$ & 612 & 611 \\
\hline$F$ & $12.08^{\dagger}(5606$ d.f. $)$ & $36.01^{\dagger}(5605$ d.f. $)$ \\
\hline Type of test & two-tailed & one-tailed \\
\hline \multicolumn{3}{|c|}{$\begin{array}{l}\text { Probabilities of } t: * p<0.05 * * p<0.01 * * * p<0.001 \text {; } \\
\text { Probability of F: }{ }^{*}<0.0000 \\
\text { Sources: U.S. Census: } 1970 \text { POP4A, } 1980 \text { STF3A, 1990 STF3A } \\
\text { Note: Standard errors (and degrees of freedom indicated by d.f.) are given in parentheses. }\end{array}$} \\
\hline
\end{tabular}


Table 8. Extreme poverty tracts in 1969, Pittsburgh Standard Metropolitan Statistical Area

\begin{tabular}{|c|c|c|c|c|c|c|c|c|}
\hline Communities & $\begin{array}{l}\text { Tract } \\
\text { No. }\end{array}$ & Population & Ppov & Mnlfu & Dropout & Whead & Assist & Black \\
\hline Central Business District & 101 & 989 & 0.414 & 0.331 & 0.068 & 0.000 & 0.775 & 0.051 \\
\hline Crawford-Roberts & 303 & 1945 & 0.530 & 0.635 & 0.301 & 0.135 & 0.229 & 0.958 \\
\hline Crawford-Roberts & 304 & 3056 & 0.407 & 0.580 & 0.228 & 0.118 & 0.341 & 0.912 \\
\hline $\begin{array}{l}\text { West Oakland }(0.82) \text { Terrace } \\
\text { Village }(0.18)\end{array}$ & 401 & 2919 & 0.460 & 0.537 & 0.242 & 0.210 & 0.349 & 0.781 \\
\hline $\begin{array}{l}\text { Terrace Village }(0.85) \\
\text { Crawford-Roberts }(.15)\end{array}$ & 503 & 2010 & 0.493 & 0.601 & 0.258 & 0.184 & 0.276 & 0.957 \\
\hline $\begin{array}{l}\text { Terrace Village }(0.85) \text { West } \\
\text { Oakland }(0.15)\end{array}$ & 504 & 3206 & 0.460 & 0.450 & 0.252 & 0.256 & 0.321 & 0.946 \\
\hline Arlington Heights & 1604 & 2003 & 0.742 & 0.659 & 0.428 & 0.473 & 0.459 & 1.000 \\
\hline $\begin{array}{l}\text { St. Clair (0.56) Mount Oliver } \\
(0.42) \text { Carrick }(0.02)\end{array}$ & 1605 & 5189 & 0.417 & 0.380 & 0.202 & 0.347 & 0.320 & 0.394 \\
\hline Central Northside & 2203 & 581 & 0.406 & 0.447 & 0.109 & 0.171 & 0.513 & 0.153 \\
\hline $\begin{array}{l}\text { North Shore (0.98) Allegheny } \\
\text { Center (0.02) }\end{array}$ & 2205 & 466 & 0.426 & 0.665 & 0.333 & 0.036 & 0.405 & 0.283 \\
\hline $\begin{array}{l}\text { North Shore }(0.84) \text { Troy Hill } \\
(0.15) \text { East Allegheny }(0.01)\end{array}$ & 2303 & 438 & 0.597 & 0.331 & 0.435 & 0.128 & 0.226 & 0.194 \\
\hline Northview Heights & 2609 & 4487 & 0.497 & 0.465 & 0.101 & 0.355 & 0.372 & 0.737 \\
\hline Braddock & 5134 & 1284 & 0.430 & 0.722 & 0.359 & 0.142 & 0.323 & 0.025 \\
\hline McKeesport & 5504 & 2129 & 0.419 & 0.510 & 0.237 & 0.141 & 0.317 & 0.265 \\
\hline Total Population & & 30702 & & & & & & \\
\hline
\end{tabular}

Sources: U.S. Census: 1970 Pop4A, City of Pittsburgh Department of City Planning 1991

substantially during this period, and various combinations of all but one of the underclass criteria used by Ricketts and Sawhill (1988) intersected in many of the other census tracts.

The extreme poverty tracts in the Pittsburgh Region are shown in Tables 8, 9, 10, and 11, along with their respective proportions for the variables (MNLFU, ASSIST, WHEAD, and DROPOUT) used by Ricketts and Sawhill (1988), and the proportion of the African-American population shows the effects of racial exclusion, particularly under conditions of rapid deindustrialization. Tables 9, 10, and 11 divide these census tracts into those which were also extreme poverty tracts in the previous decade and those which exhibited extreme poverty concentrations only as of the latest census. In 1969, 14 census tracts in the Pittsburgh region, with a total population of some 30700 met the extreme poverty criterion. In 1979, 19 census tracts met the extreme poverty criterion, with a population of some 38800 (about $1.75 \%$ of the regional population). In 1989, however, 42 census tracts met the extreme poverty criterion for underclass designation, with a total population of more than 74 200 , more than $3.5 \%$ of the total population of the region. 
Table 9. Extreme poverty tracts in 1979, Pittsburgh Standard Metropolitan Statistical Area

\begin{tabular}{|c|c|c|c|c|c|c|c|c|}
\hline Communities & $\begin{array}{l}\text { Tract } \\
\text { No. }\end{array}$ & Population & Ppov & Mnlfu & Dropout & Whead & Assist & Black \\
\hline \multicolumn{9}{|c|}{ Panel A: Extreme poverty tracts as of 1969} \\
\hline Central Business District & 101 & 1032 & 0.430 & 0.372 & 0.000 & 0.000 & 0.152 & 0.154 \\
\hline $\begin{array}{l}\text { West Oakland }(0.82) \text { Terrace } \\
\text { Village }(0.18)\end{array}$ & 401 & 3381 & 0.409 & 0.252 & 0.100 & 0.311 & 0.454 & 0.927 \\
\hline $\begin{array}{l}\text { Terrace Village }(0.85) \\
\text { Crawford-Roberts }(0.15)\end{array}$ & 503 & 1850 & 0.584 & 0.232 & 0.134 & 0.246 & 0.464 & 0.986 \\
\hline $\begin{array}{l}\text { Terrace Village (0.85) West } \\
\text { Oakland }(0.15)\end{array}$ & 504 & 2179 & 0.559 & 0.237 & 0.000 & 0.287 & 0.447 & 0.977 \\
\hline Arlington Heights & 1604 & 1438 & 0.686 & 0.199 & 0.155 & 0.708 & 0.831 & 0.959 \\
\hline Saint Clair & 1606 & 3328 & 0.640 & 0.231 & 0.071 & 0.638 & 0.584 & 0.896 \\
\hline $\begin{array}{l}\text { North Shore (0.98) Allegheny } \\
\text { Center }(0.02)\end{array}$ & 2205 & 324 & 0.597 & 0.428 & 0.000 & 0.000 & 0.313 & 0.160 \\
\hline Northview Heights & 2609 & 3217 & 0.623 & 0.230 & 0.061 & 0.474 & 0.587 & 0.913 \\
\hline Total Population & & 16749 & & & & & & \\
\hline \multicolumn{9}{|c|}{ Panel B: Extreme poverty tracts as of 1979} \\
\hline Bluff & 102 & 4504 & 0.401 & 0.247 & 0.011 & 0.091 & 0.185 & 0.154 \\
\hline West Oakland & 402 & 2192 & 0.404 & 0.206 & 0.017 & 0.030 & 0.111 & 0.308 \\
\hline Bedford Dwellings & 509 & 2878 & 0.459 & 0.243 & 0.022 & 0.318 & 0.454 & 0.950 \\
\hline Strip District & 601 & 216 & 0.520 & 0.223 & 0.000 & 0.119 & 0.143 & 0.810 \\
\hline Homewood South & 1303 & 3036 & 0.466 & 0.246 & 0.126 & 0.220 & 0.355 & 0.957 \\
\hline Glen Hazel & 1504 & 607 & 0.417 & 0.174 & 0.097 & 0.152 & 0.416 & 0.750 \\
\hline $\begin{array}{l}\text { Chateau (0.70) Manchester } \\
(0.30)\end{array}$ & 2106 & 460 & 0.424 & 0.227 & 0.000 & 0.167 & 0.340 & 0.476 \\
\hline $\begin{array}{l}\text { East Allegheny (0.94) Troy } \\
\text { Hill (0.06) }\end{array}$ & 2302 & 2122 & 0.420 & 0.311 & 0.118 & 0.048 & 0.400 & 0.039 \\
\hline $\begin{array}{l}\text { California-Kirkbride }(0.92) \\
\text { Perry South }(0.08)\end{array}$ & 2502 & 1046 & 0.520 & 0.244 & 0.000 & 0.268 & 0.472 & 0.857 \\
\hline Fairywood & 2808 & 3008 & 0.489 & 0.164 & 0.085 & 0.495 & 0.416 & 0.854 \\
\hline Braddock & 5137 & 2016 & 0.477 & 0.273 & 0.106 & 0.191 & 0.378 & 0.742 \\
\hline Total Population & & 22085 & & & & & & \\
\hline
\end{tabular}


Sources: U.S. Census: 1980 STF3A, City of Pittsburgh Department of City Planning 1991

This numerical increase in extreme poverty tracts was also concentrated spatially. In 1969, there was one primary area of extreme poverty, and a few other areas near one another but not connected. The primary area of extreme poverty ran from downtown, through the southern half of what is commonly referred to as the Hill District and into West Oakland. This included at least parts of the downtown, Crawford-Roberts, Terrace Village, and West Oakland. Two of the smaller areas were on and behind Mount Washington, the bluff rising behind the south shore of the Monongahela River: Arlington Heights and an area including parts of St. Clair, Carrick, and the Pittsburgh neighborhood of Mt. Oliver (adjacent to the Borough of Mt. Oliver). Another area included the North Shore and parts of Troy Hill, Allegheny Center, and East Allegheny. Also on the North Side, Northview Heights was an area of extreme poverty, although this was not connected with that of North Shore. Finally, the Mon Valley communities of Braddock and McKeesport each had extreme poverty tracts in 1969.

By 1979, there were 19 census tracts with extreme concentrations of poverty, but these included only half of the extreme poverty tracts from 1969. The overall population living in extreme poverty tracts did, however, increase by nearly 9000 . Thus, some communities edged out of the criterion for extreme poverty, and others had become sufficiently impoverished during the 1970 s to meet the $40 \%$ below poverty criterion. Tracts 303 and 304 from the Crawford-Roberts neighborhood between the Hill District and downtown no longer had concentrations of poverty meeting the extreme poverty criterion of $40 \%$ or higher. Tract 1605 covering parts of the St. Clair, Mt. Oliver, and Carrick neighborhoods no longer met the extreme poverty criterion in 1970 and neither did the eastern part of the North Shore neighborhood (tract 2303), or tract 5504 in McKeesport. Also, tract 5134 in Braddock was no longer an extreme poverty tract by 1979 , but Braddock tract 5137 (with some 800 more people) did meet the extreme poverty criterion by then.

Because of the significance of spatial isolation in the formation of the underclass, shifts in the contiguous areas of extreme poverty are crucial. The shifts in these areas between 1969 and 1979 were nominal compared with the expansion of these areas between 1979 and 1989. By 1989, the primary area of extreme poverty grew to cover nearly all of the Hill District, and Oakland as well. Generally, the areas where extreme poverty was concentrated over a period of 10 years or more also exhibited increases in the other manifestations of the underclass. Furthermore, the areas with the highest rates for poverty and the other underclass indicators from earlier decades were the same as those with the highest rates for poverty and the other underclass indicators in later decades, underlining the intransigence of many extreme poverty areas. Examples are Arlington Heights, St. Clair, and Northview Heights. Also, the full set of underclass indicators for the extreme poverty areas are substantially higher than the values of these indicators for the region as a whole, as shown in Table 9. Thus, the spread and persistence of extreme poverty could be viewed as a leading indicator of the other variables associated with the underclass.

It appears that the Ricketts and Sawhill (1988) criterion is too stringent in failing to identify any underclass areas in the Pittsburgh region, but the correlates of the underclass that they identified remain useful for assessing related social conditions at the community level. Although spatial isolation in extreme poverty areas on the same order as in much larger cities (for example, as in the extreme poverty areas of South and West Chicago) have not yet been characteristic of the City of Pittsburgh, the spread of extreme poverty areas and the developing connections between previously separate areas of extreme poverty may ultimately result in large ghetto areas on a scale previously unknown in Pittsburgh. Additional layoffs and plant closures, perhaps in industries besides steel, may reinforce this trend by reducing the opportunities for unskilled workers even further. Although any such local plant closures today may appear minor in comparison to those that occurred during the dramatic collapse of the steel industry, increases in extreme poverty areas and in the correlates of the underclass may result from an incremental narrowing of employment 
Table 10. Extreme poverty tracts in 1989, Pittsburgh Standard Metropolitan Statistical Area

\begin{tabular}{|c|c|c|c|c|c|c|c|c|c|}
\hline Communities & Tract No. & $\begin{array}{c}1980 \\
\text { Tract } \\
\text { No. }\end{array}$ & $\begin{array}{l}\text { Populati- } \\
\text { on }\end{array}$ & Ppov & Mnlfu & Dropout & Whead & Assist & Black \\
\hline \multicolumn{10}{|c|}{ Panel A: Extreme poverty tracts as of 1979} \\
\hline Central Business District & 101 & 101 & 1444 & 0.543 & 0.795 & 0.039 & 0.000 & 0.072 & 0.485 \\
\hline Bluff & 103 & $\begin{array}{l}102 \\
408 \\
\text { (pt.) }\end{array}$ & 3220 & 0.438 & 0.491 & 0.000 & 0.057 & 0.105 & 0.149 \\
\hline West Oakland & 411 & $\begin{array}{r}401 \\
\text { (pt.), } \\
504 \\
\text { (pt.) }\end{array}$ & 974 & 0.404 & 0.528 & 0.410 & 0.242 & 0.334 & 0.882 \\
\hline Bedford Dwellings & 509 & 509 & 2317 & 0.641 & 0.807 & 0.135 & 0.358 & 0.509 & 0.954 \\
\hline Homewood South & 1303 & 1303 & 2653 & 0.452 & 0.614 & 0.071 & 0.180 & 0.363 & 1.000 \\
\hline Glen Hazel & 1504 & $\begin{array}{r}1504, \\
1503 \\
\text { (pt.) }\end{array}$ & 793 & 0.558 & 0.856 & 0.294 & 0.145 & 0.317 & 0.692 \\
\hline Arlington Heights & 1604 & $\begin{array}{r}1604, \\
1603 \\
\text { (pt.) }\end{array}$ & 1,497 & 0.854 & 0.908 & 0.135 & 0.564 & 0.715 & 0.880 \\
\hline Saint Clair & 1606 & 1606 & 1960 & 0.751 & 0.731 & 0.190 & 0.655 & 0.604 & 0.883 \\
\hline North Shore & 2205 & 2205 & 215 & 0.521 & 0.607 & 0.000 & 0.000 & 0.383 & 0.056 \\
\hline California-Kirkbride & 2507 & 2502 & 1156 & 0.416 & 0.487 & 0.000 & 0.197 & 0.206 & 0.599 \\
\hline Northview Heights & 2609.98 & 2609 & 2,746 & 0.764 & 0.762 & 0.195 & 0.480 & 0.684 & 1.000 \\
\hline Fairywood & 2808 & 2808 & 2951 & 0.770 & 0.707 & 0.344 & 0.607 & 0.594 & 0.914 \\
\hline Total Population & & & 21926 & & & & & & \\
\hline Grand Total Population & & $\begin{array}{r}742- \\
72\end{array}$ & & & & & & & \\
\hline
\end{tabular}

Sources: U.S. Census: 1990 STF3A, City of Pittsburgh Department of City Planning 1991

opportunities because of plant closures across a range of industries that employ unskilled workers over a longer time frame. Deindustrialization within inner-city Chicago, for example, occurred over three decades and was not restricted primarily to a single industry (Wacquant and Wilson 1993:30).

\section{Shifts in Income Distribution by Race}

Economic restructuring had profound implications for the regional economy and, in particular, for its traditional employment base in the steel industry; therefore, a corresponding shift in income distribution should also be expected. This can be seen in Table 12, which shows shifts in the shape of the income distribution in constant (1982) dollars. The increases in the proportions of the population 
Table 11. Extreme poverty tracts in 1989, Pittsburgh Standard Metropolitan Statistical Area (cont.)

\begin{tabular}{|c|c|c|c|c|c|c|c|c|}
\hline Communities & \multicolumn{2}{|c|}{$\begin{array}{l}\text { Tract Population } \\
\text { No. }\end{array}$} & Ppov & Mnlfu & Dropout & Whead & Assist & Black \\
\hline \multicolumn{9}{|c|}{ Panel B: Extreme poverty tracts as of 1989} \\
\hline Crawford Roberts & 305 & 1371 & 0.418 & 0.613 & 0.093 & 0.087 & 0.274 & 1.000 \\
\hline Crawford Roberts & 314 & 1088 & 0.516 & 0.798 & 0.164 & 0.189 & 0.405 & 1.000 \\
\hline Central Oakland & 405 & 3014 & 0.564 & 0.536 & 0.000 & 0.006 & 0.049 & 0.051 \\
\hline Central Oakland & 406 & 2392 & 0.547 & 0.517 & 0.069 & 0.000 & 0.072 & 0.053 \\
\hline South Oakland & 409 & 1893 & 0.410 & 0.670 & 0.397 & 0.032 & 0.087 & 0.404 \\
\hline Middle Hill & 501 & 1114 & 0.481 & 0.715 & 0.214 & 0.077 & 0.403 & 0.978 \\
\hline Middle Hill & 502 & 1076 & 0.425 & 0.506 & 0.000 & 0.258 & 0.370 & 0.947 \\
\hline North Oakland & 507 & 1144 & 0.563 & 0.571 & 0.000 & 0.010 & 0.226 & 0.123 \\
\hline Terrace Village & 510 & 3523 & 0.732 & 0.639 & 0.308 & 0.446 & 0.487 & 1.000 \\
\hline Terrace Village & 511 & 1550 & 0.805 & 0.876 & 0.324 & 0.276 & 0.568 & 0.953 \\
\hline Garfield & 1016 & 2130 & 0.554 & 0.649 & 0.381 & 0.253 & 0.501 & 0.942 \\
\hline Larimer & 1204 & 1953 & 0.481 & 0.608 & 0.088 & 0.238 & 0.399 & 0.844 \\
\hline Homewood West & 1207 & 1369 & 0.418 & 0.631 & 0.172 & 0.142 & 0.320 & 0.892 \\
\hline Larimer & 1208 & 2039 & 0.407 & 0.616 & 0.037 & 0.130 & 0.273 & 0.875 \\
\hline Homewood North & 1305 & 1303 & 0.444 & 0.525 & 0.234 & 0.295 & 0.301 & 0.988 \\
\hline East Hills & 1306 & 4505 & 0.400 & 0.537 & 0.146 & 0.194 & 0.345 & 0.953 \\
\hline South Shore & 1921 & 44 & 0.692 & 0.000 & 0.000 & 0.000 & 0.000 & 0.182 \\
\hline Allegheny Center & 2204 & 1262 & 0.413 & 0.513 & 0.000 & 0.033 & 0.068 & 0.368 \\
\hline East Allegheny & 2305 & 1334 & 0.444 & 0.620 & 0.000 & 0.059 & 0.221 & 0.165 \\
\hline Perry South & 2603 & 515 & 0.400 & 0.583 & 0.412 & 0.077 & 0.195 & 0.583 \\
\hline McKees Rocks & 4644 & 4509 & 0.449 & 0.469 & 0.067 & 0.193 & 0.267 & 0.233 \\
\hline West Homestead & 4824 & 893 & 0.449 & 0.474 & 0.422 & 0.091 & 0.205 & 0.185 \\
\hline Clairton & 4923 & 761 & 0.580 & 0.672 & 0.244 & 0.264 & 0.398 & 0.962 \\
\hline Rankin & 5140 & 2503 & 0.407 & 0.588 & 0.127 & 0.208 & 0.257 & 0.570 \\
\hline McKeesport & 5521 & 1990 & 0.531 & 0.795 & 0.312 & 0.146 & 0.341 & 0.588 \\
\hline
\end{tabular}




\begin{tabular}{lcccccccc}
\hline Aliquippa & 6045 & 4155 & 0.449 & 0.744 & 0.018 & 0.200 & 0.311 & 0.815 \\
Washington & 7041 & 1642 & 0.527 & 0.647 & 0.026 & 0.078 & 0.337 & 0.222 \\
New Kensington & $800-$ & 1227 & 0.562 & 0.720 & 0.280 & 0.097 & 0.365 & 0.316
\end{tabular}

Total Population

46873

Grand Total Population

74272

caught within two lowest income strata over this 20year period are apparent. However, it is the declines in the middle-income strata, particularly within the $\$ 30000-\$ 40000$ range during the 1980 s, that show the consequences of the displacement of the unionized blue-collar manufacturing economy by an economy dominated by the constellation of various jobs lumped together under the rubric of the service economy.

Of course, none of the forces involved with the economic restructuring in the Pittsburgh region during this period were color blind. The shifts in income distribution are shown separately for predominantly white and African-American neighborhoods (Table 12, Panels B and C). Of course, the overall shifts shown in Panel A of Table 12 are largely reproduced in Panel B, which shows the changes for the majority of the population. Within predominantly African-American neighborhoods, however, the proportion of the population within the lowest income stratum doubled during the 1970s, and then doubled again during the 1980s. The income declines within predominantly AfricanAmerican neighborhoods were not, however, isolated to the poor. All the income strata from $\$ 15$ 000 and up in these neighborhoods declined substantially during the 1970s and 1980s, with merely a few percentage points rise in the strata from $\$ 40000$ and above during the 1980s following the increases of income among the wealthiest during this period.

Regional economic restructuring and the rough shifts in income for the population as a whole, and broken down by racial composition of neighborhood, indicate: 1) that the local shifts in social structure covered more than the just the underclass and its adjacent strata; and 2) that the impacts on the social structures of white and African-American
Pittsburgh were not the same. In particular, the middle-class earnings strata in predominately African-American neighborhoods of the Pittsburgh region shrank considerably, whereas the lowest earnings strata (with annual incomes up to $\$ 7000$ 1982 dollars) more than doubled in size. This emphasizes the importance of examining the differential impacts on minority groups when examining social structural shifts as a consequence of economic restructuring.

\section{DISCUSSION}

Although, in principle, the transformation of steel from a highly centralized "smokestack" industry to a decentralized recycling industry may be laudable, this transition was not the result of careful, environmentally and socially sensitive planning. It carried substantial human costs, while shifting the environmental impacts of steel production from highly concentrated air and water pollution and mining to the dispersion of production sites where suitable concentrations of scrap could be found, often including greenfield areas at the edges of major cities with easy access to the interstate highways, contributing to suburban sprawl.

It cannot be overemphasized that brownfield redevelopment initiatives are insufficient to put the brakes on sprawl, although facilitating the reuse of abandoned industrial sites is an important part of changing the investment psychology of the "urban growth machine" (Lyon et al. 1981, Krannich and Humphrey 1983, Logan and Molotch 1987). As explained by Jaret et al. (2000:113):

Problems of unequal and uneven development [are seen with] wider recognition that suburban sprawl is literally a constructed outcome, and that in most communities a specific set of people work at 
Table 12. Average percentages of households at various income levels by race: 1969, 1979, and 1989, Pittsburgh Standard Metropolitan Statistical Area

\begin{tabular}{|c|c|c|c|}
\hline \multirow[b]{2}{*}{ Rough adjusted income strata } & \multirow[b]{2}{*}{1969} & \multicolumn{2}{|c|}{$\begin{array}{c}\text { Average Percentages } \\
(100=1980-1982 \text { dollars })\end{array}$} \\
\hline & & 1979 & 1989 \\
\hline \multicolumn{4}{|l|}{ Panel A. All Neighborhoods } \\
\hline$<\$ 3000$ & 2.0 & 4.0 & 7.3 \\
\hline$\$ 3000-\$ 7000$ & 6.6 & 9.7 & 12.9 \\
\hline$\$ 7000-\$ 10000$ & 4.5 & 8.3 & 5.8 \\
\hline$\$ 10000-\$ 15000$ & 9.9 & 15.6 & 15.2 \\
\hline$\$ 15000-\$ 21000$ & 15.0 & 14.1 & 13.8 \\
\hline$\$ 21000-\$ 30000$ & 31.0 & 20.0 & 17.8 \\
\hline$\$ 30000-\$ 40000$ & 13.5 & 16.0 & 9.4 \\
\hline$\$ 40000-\$ 60000$ & 13.5 & 8.3 & 11.4 \\
\hline$>\$ 60000$ & 4.0 & 4.0 & 6.4 \\
\hline \multicolumn{4}{|c|}{ Panel B. Predominantly white neighborhoods } \\
\hline$<\$ 3000$ & 1.7 & 3.5 & 6.1 \\
\hline$\$ 3000-\$ 7000$ & 6.2 & 8.9 & 12.1 \\
\hline$\$ 7000-\$ 10000$ & 4.3 & 8.0 & 5.6 \\
\hline$\$ 10000-\$ 15000$ & 9.7 & 15.3 & 15.2 \\
\hline$\$ 15000-\$ 21000$ & 14.9 & 14.3 & 14.0 \\
\hline$\$ 21000-\$ 30000$ & 31.6 & 20.6 & 18.4 \\
\hline$\$ 30000-\$ 40000$ & 13.8 & 16.6 & 9.8 \\
\hline$\$ 40000-\$ 60000$ & 13.8 & 8.7 & 12.0 \\
\hline$>\$ 60000$ & 4.0 & 4.2 & 6.9 \\
\hline \multicolumn{4}{|c|}{ Panel C. Predominantly Black Neighborhoods } \\
\hline$<\$ 3000$ & 5.6 & 10.7 & 19.5 \\
\hline$\$ 3000-\$ 7000$ & 13.9 & 21.0 & 22.4 \\
\hline$\$ 7000-\$ 10000$ & 7.6 & 12.3 & 7.4 \\
\hline
\end{tabular}




\begin{tabular}{lrrr}
$\$ 10000-\$ 15000$ & 14.0 & 18.9 & 15.2 \\
$\$ 15000-\$ 21000$ & 16.1 & 12.2 & 11.6 \\
$\$ 21000-\$ 30000$ & 21.3 & 12.0 & 11.7 \\
$\$ 30000-\$ 40000$ & 8.6 & 8.3 & 4.9 \\
$\$ 40000-\$ 60000$ & 9.2 & 3.4 & 5.3 \\
$>\$ 60000$ & 3.6 & 1.0 & 1.9 \\
\hline
\end{tabular}

Sources: U.S. Census: 1970 Pop4A, 1980 STF3A, 1990 STF3A, Consumer Price Index

producing it; many of them profit handsomely from $i$, while other parties either miss out on the benefits of growth or are actually disadvantaged as a result of it.... City and suburban growth does not unfold under the direction of a "master plan" drawn up by planners and citizens for the good of the public in general, not does it emerge from a scheme created by a small, unified cabal of powerful people. Rather, urban expansion and sprawl are advocated by.... "growth coalition"-a network of active developers and other well-placed people linked across public and private sectors and across local, municipal, county, regional, state, and federal levels, who.... give greatest priority to the idea that people who own and/or develop real estate have the right to use it in the way that brings them the most financial profit....[This leads to] a number of community problems, such as disinvestment from certain neighborhoods (redlining), road and land-use decisions that favor some people and hurt others, racial and income segregation, high concentrations of homeless persons in certain areas, spatially unequal educational opportunities, and overexposure in certain neighborhoods to pollution or stigmatized activities (e.g., strip clubs, porn shops).

Although job generation in sprawl areas contributes to job growth nationally, entry-level job growth is typically far removed from the large concentrations of poorer urban minorities who could most benefit from access to it. As a rule, the pay offered by these entry-level jobs is insufficient to offer upward mobility to the urban poor. In response to the University of Pittsburgh/Carnegie Mellon University collaborative initiative on brownfield redevelopment, Krinke et al. (2001:70) state "The challenge we are facing as we move into the twenty-first century is not only to remediate contamination, but to create thoughtfully designed healthy communities that overcome the environmental ravages of our history." The difficulty of such community redesign for the urban poor is the well-documented proliferation of urban gentrification patterns that transform low-cost neighborhoods into upscale, middle- and high-income neighborhoods. Without a fundamental shift in our urban planning priorities, proposals that offer halfway measures instead of opening mobility between entry-level opportunities and the neighborhoods where they are most desperately needed will perpetuate the socioeconomic exclusion suffered by the urban poor.

In the era when industrial organization was highly centralized, unions secured living wages for large numbers of workers in jobs with low educational prerequisites. The standard of living reached by the working class came about through their labor, but also through the hidden costs of industrial pollution and consumer wastes. Public tolerance of pollution emissions at the levels seen in the 1960s and 1970s is over. With the deindustrialization and disappearance of manufacturing jobs from older industrial sites, the circulation of capital within older working-class communities diminished, affecting local businesses, neighborhoods, public services, and property values. Because previous work sites were tied up in brownfields with even more negative incentives for property reinvestment, investors' interests were deflected from these sites in favor of greenfields. Today's brownfields were once greenfields. Failure to address the abandonment of brownfields sets precedents for urbanization processes based on the consumption of greenfields, and economic revitalization of core city areas is disregarded. The throw-away society is still with us. It has shifted to a higher level: from producer and consumer waste to land-use waste.

The former industrial sites and the deteriorated 
neighborhoods surrounding them will obviously not return to a pristine state, nor is it likely that they will be returned to agriculture. Older industrial regions in the U.S. have, in effect, found their air and water pollution and manufacturing jobs traded off for territory still populated by many residents unable to adjust to the shifting labor market and stigmatized to further capital investment. Because attracting real-estate investment is in the interests of suburban jurisdictions, core cities have few effective legislative or political options to compete with suburban growth coalitions; in the tug-of-war for real-estate investment the suburbs usually win. Therefore, common interest in attracting investment capital back to abandoned industrial sites and their surrounding communities needs to be pursued at higher levels of jurisdiction and should, obviously, be pressed by broad-based coalitions. Tipping the package of incentives for real-estate investment back in favor of the core cities is essential for brownfield redevelopment. Therefore, top priority should be given to lifting the perceptions and realities of liability risk for potential brownfield investors. Independent site evaluations and audits empowered to provide approved-use zoning certification that waves liability for specific land uses appropriate to the levels and types of remaining pollution would help free up brownfields from their investment freeze, and simultaneously avoid incidents reminiscent of the Love Canal tragedy. The expansion of the homogenous built landscapes profit a well-heeled minority at the expense of rational land conservation and planning. Planning for preservation of open space, farmlands, and wildlife habitats could be coordinated with the core cities to help in their economic revitalization and that of their long-depressed neighborhoods and communities.

Responses to this article can be read online at:

http://www.ecologyandsociety.org/vol10/iss 1/art13/responses/

\section{Acknowledgments:}

I thank Vijai P. Singh and the University of Pittsburgh's University Centerfor Social and Urban Research for their generous support during the early phases of this research; Alejandro Portes and Princeton University's Department of Sociology, Office of Population Research and the Center for Migration and Development for their support during the later phases; and Craig Allen for bringing the opportunity to prepare my work for this issue of Ecology and Society to my attention. Tables 1 through 7 and Table 12 are reprinted from Research in Stratification and Social Mobility, vol. 22, William J. Haller. "Changes in the Structure of Status Systems: Employment Shifts in the Wake of Deindustrialization," pages 119-148. Copyright (2005), with permisssion from Elsevier. All responsibility for any errors or omissions is mine alone.

\section{LITERATURE CITED}

Alderson, A. S. 1997. Globalization and deindustrialization: direct investment and decline of manufacturing employment in 17 OECD nations. Journal of World-Systems Research 3(1):1-34.

Anderson, E. 1990. Streetwise: race, class, and change in an urban community. University of Chicago Press, Chicago, Illinois, USA.

American Iron and Steel Institute. Various Years. Annual Statistical Report. American Iron and Steel Institute, Washington, D.C., USA.

Barnett, D. F., and R. W. Crandall. 1986. Up from the ashes: the rise of the steel minimill in the United States. The Brookings Institution, Washington D. C., USA.

Beeson, P., and F. Giarratani. 1998. Spatial aspects of capacity change by U.S. integrated steel producers. Journal of Regional Science 38(3):425444.

City of Pittsburgh, Department of City Planning. 1991. Report no. 1: Pittsburgh population by neighborhood, 1940-1990. 1990 Census of Population and Housing Reports. Department of City Planning, Pittsburgh, Pennsylvania, USA.

Dicken, P. 1992. Global shift: the internationalization of economic activity. Second edition. Paul Chapman Publishing, London, UK.

Dickerson, D. C. 1986 . Out of the crucible: black steelworkers in western Pennsylvania, 1875-1980. In J. Howard and R. Smith, editors. SUNY Series 
in Afro-American Studies. State University of New York Press, Albany, New York, USA.

Fernández-Kelly, M. P. 1995. Social and cultural capital in the urban ghetto: implications for the economic sociology of immigration. Pages 213247 in A. Portes, editor. The economic sociology of immigration: essays on networks, ethnicity, and entrepreneurship. Russell Sage Foundation, New York, New York, USA.

Fröbel, F., J. Heinrichs and O. Kreye. 1980. The new international division of labor: structural unemployment in industrialised countries and industrialisation in developing countries. Cambridge University Press, Cambridge, UK.

Gdovic, R., and W. Haller. 1994. On-line databases and geographic information systems for environmental research : a geographic perspective on air and water quality. University Center for Social and Urban Research, University of Pittsburgh, Pittsburgh, Pennsylvania, USA.

Geltman, E. G. 2000. Recycling land: understanding the legal landscape of brownfield development. The University of Michigan Press, Ann Arbor, Michigan, USA.

Hall, C. G. L. 1996. Steel phoenix: the fall and rise of the U.S. steel industry. St. Martin's Press, New York, New York, USA.

Haller, W. 2005. Changes in the structure of status systems: employment shifts in teh wake of deindustrilization. Research in Stratification and Social Mobility 22:119-148.

Haller, W., and V. P. Singh. 1996. Technology, producer services, and the new international division of labor. Journal of Developing Societies 12(1):4-18.

Haller, W. 1999. Regional restructuring and underclass growth: impacts of manufacturing decline in the Pittsburgh metropolitan area. Dissertation, University of Pittsburgh, Pittsburgh, Pennsylvania, USA.

Heraclito de Lima, J. G. 1991. Restructuring the U.S. steel industry: semi-finished steel imports, international integration, and U.S. adaptation. Westview Press, Boulder, Colorado, USA.
Hoerr, J. P. 1988. And the wolf finally came: the decline of the American steel industry. University of Pittsburgh Press, Pittsburgh, Pennsylvania, USA.

Jaret C., E. P. Ruddiman, and K. Philips. 2000. The legacy of residential segregation. Pages 111138 in R. D. Bullard, G. S. Johnson and A. O. Torres, editors. Sprawl city: race, politics, and planning in Atlanta. Island Press, Washington D.C., USA.

Kasarda, J. D. 1988. Jobs, migration and emerging urban mismatches. Pages 148-198 in M. G. McGreary, H. Lynn, and L. E. Lynn, Jr., editors. Urban change and poverty. National Academy Press, Washington D.C., USA.

Krannich, R. S. and C. R. Humphrey. 1983. Local mobilization and community growth: toward an assessment of the "growth machine" hypothesis. Rural Sociology 48(1):60-81.

Koritz, D. 1991. Restructuring or destructuring? Deindustrialization in two industrial heartland cities. Urban Affairs Quarterly 26(4):497-511.

Krinke, R., D. Winterbottom, and N. Kirkwood. 2001. Response, living laboratories: studies in infrastructure and industrial land. Pages 69-71 in N. Kirkwood, editor. Manufactured sites: rethinking the postindustrial landscape. Spon Press, London, UK.

Logan, J. R., and H. L Molotch. 1987. Urban fortunes: the political economy of place. University of California Press, Berkeley, California, USA.

Lyon, L., L. G. Felice, M. R. Perryman, and S. Parker. 1981. Community power and population increase: an empirical test of the growth machine model. American Journal of Sociology 86(6):13871400 .

Massey, D. S., and N. A. Denton. 1993. American apartheid: segregation and the making of the underclass. Harvard University Press, Cambridge, Massachussetts, USA.

Organisation for Economic Co-operation and Development (OECD) Secretariat of the Steel Committee. 1995. World steel trade, 1983-1993. OECD, Paris, France.

Price, V. C. 2001. Some causes and consequences of fragmentation. Pages 88-107 in S. W. Arndt and 
H. Kierzkowski, editors. Fragmentation: new production patterns in the world economy. Oxford University Press, Oxford, UK.

Ricketts, E. R., and I. V. Sawhill. 1988. Defining and measuring the underclass. Journal of Policy Analysis and Management 7(2):316-325.

Singh, V. P. 1991. The underclass in the United States: some correlates of economic change. Sociological Inquiry 61(4):505-521.

Singh, V. P., and Borzutsky. 1988. The state of the mature industrial regions in western Europe and North America. Urban Studies 25(3):212-227.

U.S. Bureau of Economic Analysis. 1997. Regional economic information system: 19691996. CD-ROM. U.S. Department of Commerce, Washington, D.C., USA.

U.S. Bureau of Labor Statistics. 1996. Consumer price index. U.S. Bureau of Labor Statistics, Washington, D.C., USA.

U.S. Bureau of the Census. 1970. Census of population and housing 1970. Fourth count summary tapes, File A. Princeton University Data Archives, Study Number 808. Bureau of the Census, Washington, D.C., USA.

U.S. Bureau of the Census. 1980. Census of population and housing 1980. Summary tapes, File $3 \mathrm{~A}$ [computer file]. Inter-University Consortium for Political and Social Research, Ann Arbor, Michigan, USA [distributor]. Bureau of the Census [producer], Washington, D.C., USA.

U.S. Bureau of the Census. 1983. Census tracts, Pittsburgh PA: standard metropolitan statistical area. 1980 Census of population and housing. U.S. Department of Commerce, Washington, D.C., USA.

U.S. Bureau of the Census. 1992. Census of population and housing 1990. Summary tapes, File 3 (CD-ROM). Bureau of the Census, Washington, D.C., USA.

U.S. Bureau of the Census. 1993. Population and housing characteristics for census tracts and block numbering areas, Pittsburgh PA PMSA. 1990 Census of population and housing. U.S. Department of Commerce, Washington, D.C., USA.
U.S. Bureau of the Census. 1994. Geographical areas reference manual. U.S. Department of Commerce, Washington, D.C., USA.

Wacquant, L. J., and W. J. Wilson. 1993. The cost of racial and class exclusion in the inner city. Pages 25-42 in W. J. Wilson, editor. The ghetto underclass: social science perspectives. Sage Publications, Newbury Park, California, USA.

Wilson, W. J. 1980. The declining significance of race: Blacks and changing American institutions. Second edition. University of Chicago Press, Chicago, Illinois, USA.

Wilson, W. J. 1990. The truly disadvantaged: the inner city, the underclass, and public policy. Second edition. The University of Chicago Press, Chicago, Illinois, USA.

Wilson, W. J. 1993. The underclass: issues, perspectives, and public policy. Pages 1-24 in W. J. Wilson, editor. The ghetto underclass: social science perspectives. Sage Publications, Newbury Park, California, USA.

Wilson, W. J. 1996. When work disappears: the world of the new urban poor. Alfred A. Knopf, New York, New York, USA. 
APPENDIX 1. Data Sources, Variables Used, and Comparability Issues

The data used for this research are the tract-level data from the Decennial Censuses of 1970, 1980, and 1990 for the Pittsburgh Standard Metropolitan Statistical Area (SMSA), which includes Allegheny, Beaver, Washington, and Westmoreland Counties. These data published by the Census Bureau are the Population Counts 4A (Counts 4A) for 1970, and the Summary Tape Files 3A (STF3A) for 1980 and 1990. The tractlevel data provide estimates for the entire population within tracts, based on a $20 \%$ sample from the long form of the Decennial Census. Because of changes in the variables provided by the Census Bureau and in the numbering and boundaries of many of the census tracts in the Pittsburgh SMSA during the 20-year period under review, certain comparability issues arise between the variables (particularly with the 1970 data), and between the census tracts themselves in the data sets for 1970, 1980, and 1990. These comparability issues were resolved using the Census Tract Comparability Charts (U.S. Bureau of the Census, 1983 and 1993).

\section{The Variables and their Comparability over Time}

The STF3A for 1990 was designed to be comparable with the STF3A for 1980, thus the discussion primarily concerns the comparability of the variables between the Counts 4A for 1970 and the STF3A for 1980 and 1990. These variables are measures of employment structure, the composition of employment by industry and occupation of the populations of each tract; and underclass indicators, the proportion of the population in each census tract measured by any of the five variables used to identify the underclass.

\section{Employment Structure Measures}

The Census Bureau maintained comparability between the 1980 and 1990 censuses so the categories for the Standard Industrial Classifications (SIC) and the Occupational Titles provided in the STF3A were nearly identical for these 2 years. The only difference was in employment counts for the industry "Personal Services" which, in the 1980 STF3A, also included "Entertainment and Recreation Services." These industry groups were aggregated in the 1980 STF3A, so they also had to be aggregated for the 1970 and 1990 data sets to make the employment counts for "Personal Services" comparable for all three panels. This was the only modification required to make the industrial and occupational categories comparable between the 1980 and 1990 panels.

The industrial and occupational classifications for the Counts 4A for 1970 were considerably more detailed than the classifications in the STF3A for 1980 and 1990. Therefore, aggregating the employment counts for industrial and occupational classifications made the labor market measures in the 1970 panel comparable with those in 1980 and 1990.

\section{Underclass Indicators}

The underclass indicators from the 1980 and 1990 Censuses are fully comparable. However, the variables from the 1970 Census do not share the same degree of comparability. Specifically, the 1970 questions for households headed by women with children (WHEAD) and public assistance (ASSIST) were based on families rather than households. However, household living arrangements coincided with nuclear families to a greater extent in 1970 than in 1980 or 1990. Thus, the proportions for WHEAD and ASSIST may be underestimated for 1970, but not to a great extent. Additionally, the school enrollment and employment questions, which provide the counts for youths who have dropped out of high school (DROPOUT), covered the 16- to 21-year age group, rather than those aged 16 to 19. Therefore, the DROPOUT indicator for 1970 is somewhat inflated.

The Units of Analysis and their Comparability over Time

Census tracts comprise the units of analysis used in this research. According to the Census Bureau's Geographical Areas Reference Manual (U.S. Bureau of the Census, 1994:10-1), "Census tracts are small, 
relatively permanent geographic entities within counties (or the statistical equivalents of counties) delineated by a committee of local data users." Nevertheless, census tracts are still sometimes subject to change from decade to decade. Because census tract boundaries were changed in several instances in the Pittsburgh SMSA from 1970 to 1980, and from 1980 to 1990, the Census Tract Comparability Charts for the 1980 and 1990 Censuses were used as a guide to trace the tract changes from the previous decade. Aggregating tracts for comparability produced a data set with 615 comparable observations from each census. The labeling conventions used by the Census Bureau to indicate the presence and types of tract changes serve as a guide to the kinds of changes that were implemented. The few tracts with the suffix, ".99" were removed from the data set to exclude people living on ships or boats. Tracts that were split after 1970 were aggregated together again, because comparability with the 1970 tracts took precedence over attempting to maintain roughly homogeneous population sizes. In all instances of aggregating split or altered tracts into superior units of analysis, the Census Tract Comparability Charts are used as a guide to the changes in the tract boundaries and their labeling. 